\title{
Investment Performance of Islamic Bank: An Empirical Study
}

\section{Evana Nusrat Dooty ${ }^{1}$, Mohammed Syedul Islam²}

${ }^{1}$ Lecturer in Economics, Department of Business Administration, International Islamic University Chittagong

${ }^{2}$ Assistant Professor in Economics, Department of Business Administration, International Islamic University Chittagong

\begin{abstract}
The article undertakes an empirical study on investment of Islamic Bank. The aim of the study is to examine and evaluate the performance of investment of Islamic Bank for the time period 2005-2009 in comparison with a conventional Bank. Several financial ratios are applied for this purpose. For the empirical investigation data has been collected from Islami Bank Bangladesh Limited and Mutual Trust Bank Limited. The study found that Islami Bank Bangladesh Limited (IBBL) is relatively less profitable and less risky (more solvent) during 2005-2009 compared to a conventional bank (Mutual Trust Bank Limited), however, it is improving considerably over time indicating convergence with the performance of the conventional banks.
\end{abstract}

Key Words: Islamic bank, conventional bank, profitability, deployment, liquidity, risk JEL Classification Code: G24; P45

\section{INTRODUCTION}

Ts slamic banking started on a modest scale in the early 1970s and has shown tremendous growth over the last 30 years. What started as a small rural banking experiment in the remote villages of Egypt has now reached a level where many mega-international banks are offering Islamic banking products. The practice of Islamic banking now spreads from East to West, all the way from Indonesia and Malaysia towards Europe and the America. The size of the industry that amounted to a few hundred thousands of dollars in 1975 had reached hundreds of billions of dollars by 2004. Research in the first stage is considered descriptive and focusing on the conceptual issues underlining interest-free financing. In the second stage, several ratio analysis are used to examine the theoretical framework of the Islamic institutions and analyze their behavior Yet, the lack of detailed data on bank behavior and operations impeded any comprehensive empirical analysis of the experience of the last two decades. Very few attempts have so far been made to empirically analyze the investment performance of the Islamic banks (Bashir, Darrat and Suliman, 1993). When Islamic banks were assessed, their financial returns were compared with those of interest-based banks. Their success was measured by their ability to mobilize and efficiently allocate resources to generate comparable returns for their depositors and shareholder. This paper is an attempt to apply recent theories of banking firms to analyze the investment performance of Islami Bank Bangladesh Limited (IBBL). Although the choice of the following bank is dictated primarily by data availability and popularity.

\section{Literature Review}

Bangladesh Bank has been following the CAMEL rating to rank the banks based on their financial performance. Under this rating, significant issues like capital adequacy, asset management, managerial efficiency, earnings quality and liquidity are employed. However, no specific index has been identified to contrast the Islamic bank sector performance with that of the conventional bank sector performance. According to Al-Shamrnari and Salirni (1998) profitability ratio especially return on equity (ROE) signals the earning capability of the organization. They also suggest that higher return on equity (ROE) ratio is appreciable as it is the primary indicator of bank's profitability and functional efficiency. Ahmad and Pandey (2010) analyzed the profitability ratios, efficiency ratios, asset quality ratios, capital adequacy ratios, leverage ratio, liquidity ratios to measure the comparative performance of conventional banks vis-a - vis Islamic banks in the Gulf cooperation council (GCC) region during the quarters of 2006-2009. The study found that Islamic banks are more volatile than conventional banks

Many Islamic bank studies have examined the Shari'ah principles behind offering such finance (ulamas) but historically limited financial analysis was performed, often due to data availability limitations (e.g. Ariff, 1988). Data still remains a problem and so cross sectional studies tend to dominate the literature. One such efficiency performance study by Yudistira (2003) revealed that non-Middle Eastern Islamic banks were more efficient than Middle Eastern banks which, given the development of Islamic banks in that region, was surprising. Also larger Islamic banks were more efficient than smaller ones.

The evidence as to whether Islamic banks are actually more efficient than conventional banks remains quite mixed. Yudistira (2004), for example, with a global sample of 18 Islamic banks, found Islamic banks to be more efficient than conventional banks. In contrast, Hassan (2006) in a larger study of 43 Islamic banks found them somewhat less cost efficient than conventional banks. Finally, while not 
examining efficiency, Cihak and Hesse (2008) found smaller Islamic banks tended to be financial stronger than larger ones. One issue in Islamic banking is the degree to which Shari'ah law is actually followed.

\section{ObJectives}

The main objective of the study is to examine the investment performance of Islamic bank. Since the definition of investment is very broad, we would like to focus on the following specific objectives.

- To focus on the investment activities in Islamic Banking.

- To analyze the investment trend of Islamic Bank

- To enlighten on investment performance of interest free Islamic Bank and interest based conventional bank through profitability ratio, deployment ratio, liquidity ratio and risk ratio and to draw comparisons

\section{Methodology}

\subsection{Data and Information}

The study is aimed at investment performance of Islamic banking. And also to compare it with conventional banking. Specifically, study makes comparison of Islami Bank Bangladesh Limited (IBBL) and a conventional bank's performances year in 2005-2009. Data for each year have been compiled from the income statements and balance sheets of these banks.

\subsection{Analytical Framework}

In order to see how Islamic bank has performed in comparison with the conventional banks over 5 years, the study uses 11 financial ratios for the bank's investment performance. These ratios are broadly categorized into four groups: (a) profitability ratio (b) deployment ratio (c) liquidity ratio and $(\mathrm{d})$ risk ratio.

For profitability analysis, the following three widely used financial ratios are measured:

- Return on Asset $(\mathrm{ROA})=$ Net profit after tax / Total assets

- Return on Equity $(\mathrm{ROE})=$ Net profit after tax / Share holder's equity

- Earnings per Share (EPS) $=($ Total Distributable Profit $/$ Average Number of Shares ) $\times 100$

We have calculated two types of deployment ratio.

- Deployment Ratio 1 = Total Investment/Total Equity + Total Deposits

- Deployment Ratio $2=$ Total Investment/Total Liabilities

For liquidity analysis, the following four widely used financial ratios are measured:

- Loan to Deposit Ratio (LDR) = Total loan/ Total deposit

- Loan to Asset Ratio $($ LAR $)=$ Total loan / Total asset
- Equity Multiplier $(\mathrm{EM})=$ Total asset $/$ total share holder's equity

- Current Ratio = Current assets / current liabilities

For risk analysis, the following two widely used financial ratios are measured:

- Debt-Equity Ratio $(\mathrm{DER})=$ Total debt / Total share holder's equity

- Bad Debt Ratio $(B D R)=($ Total Bad Investment $/$ Total investment) $\times 100$

\section{FINDINGS}

\subsection{Profitability Analysis}

5.1.1 ROA: our analysis of profitability measures indicates that conventional bank shows better managerial performance and efficient utilization of the assets from Islamic bank in Return on Assets (ROA) . However, it seems that, Islamic bank is getting closer to conventional banks in an upward trend; it is not inconceivable that in the near future that Islamic bank might outperform the conventional banks.

5.1.2 ROE : Further analysis of ROE reveals that Overall, $\mathrm{ROE}$ is found rising for Islamic bank and plummeting for the conventional bank during 2005-2009 mainly due to the difference in equity base and profit level of the bank. Net Profits of Islamic bank are found to increase more rapidly than its equity base causing ROE to increase, whereas, the opposite happened for conventional banks causing ROE to fall over time. However, the ROE for conventional found rising from 2008.

5.1.3 EPS: Results indicate that the earnings per share is very much fluctuating. After having drastic decrease, in 2008 both banks recovered their EPS. But EPS of IBBL increased from 30.04 to 43.30 (44.14\%) and EPS of MTBL increased from 14.80 to 21.06 (increased 42.36\%). In 2009 both banks recovered fully. It was increased from 43.30 to 55.10 for IBBL and increased from 21.07 to 46.46 for MTBL. Finally the average EPS of MTBL is 33.60 and EPS of IBBL is 42.80 which is strongly higher than MTBL.

\subsection{Deployment Ratio}

Further analysis of Deployment Ratio strengthens our finding. Examination of deployment ratio, of the two sets of banks shows that the ratio of Islamic bank is better than conventional bank. For the both ratio, Islamic bank deserves satisfactory condition where as the conventional bank found in fluctuating tendency.

\subsection{Liquidity Analysis}

5.3.1 LDR: Conventional bank is found to be more liquid than Islamic bank in terms of LDR. Findings also show that while LDR of the conventional bank is higher for sometimes than Islamic bank. This trend is due to increase in its deposits base which can be considered a positive and a good sign for the Islamic bank in that Islamic banking is making inroads into the society. 


\begin{tabular}{|c|c|c|c|c|c|c|c|c|c|c|c|c|c|c|c|c|c|c|c|c|c|c|}
\hline \multirow{3}{*}{ Yeár } & \multicolumn{6}{|c|}{ Profitability Ratio } & \multicolumn{4}{|c|}{ Deployment Ratio } & \multicolumn{8}{|c|}{ Liquidity Ratio } & \multicolumn{4}{|c|}{ Risk Ratio } \\
\hline & \multicolumn{2}{|c|}{ ROA (\%) } & \multicolumn{2}{|c|}{ ROE (\%) } & \multicolumn{2}{|c|}{ EPS } & \multicolumn{2}{|c|}{ D 1 (\%) } & \multicolumn{2}{|c|}{ D 2 (\%) } & \multicolumn{2}{|c|}{ LDR (\%) } & \multicolumn{2}{|c|}{ LAR $(\%)$} & \multicolumn{2}{|c|}{ EM } & \multicolumn{2}{|c|}{ CR } & \multicolumn{2}{|c|}{ DER } & \multicolumn{2}{|c|}{ BDR (\%) } \\
\hline & IB & MT & IB & MT & IB & MT & IB & MT & IB & MT & IB & MT & IB & MT & IB & MT & IB & MT & IB & MT & IB & MT \\
\hline $\begin{array}{l}2005 \\
2006\end{array}$ & $\begin{array}{c}1.0 \\
1.03\end{array}$ & $\begin{array}{l}1.74 \\
1.82\end{array}$ & $\begin{array}{l}13.51 \\
13.42\end{array}$ & $\begin{array}{l}5.61 \\
6.03\end{array}$ & $\begin{array}{l}48.76 \\
36.84\end{array}$ & $\begin{array}{l}35.37 \\
50.32\end{array}$ & $\begin{array}{r}24.6 \\
23.91\end{array}$ & $\begin{array}{l}19.69 \\
21.44\end{array}$ & $\begin{array}{l}84.75 \\
83.51\end{array}$ & $\begin{array}{l}80.93 \\
76.47\end{array}$ & $\begin{array}{l}86.89 \\
85.77\end{array}$ & $\begin{array}{l}89.28 \\
83.50\end{array}$ & $\begin{array}{l}79.08 \\
77.95\end{array}$ & & $\begin{array}{l}14.95 \\
15.01\end{array}$ & & $\begin{array}{l}1.07 \\
1.07\end{array}$ & $\begin{array}{l}1.08 \\
1.08\end{array}$ & $\begin{array}{l}23.93 \\
19.72\end{array}$ & $\begin{array}{l}9.29 \\
9.76\end{array}$ & $\begin{array}{l}2.24 \\
2.18\end{array}$ & $\begin{array}{l}0.00 \\
.02\end{array}$ \\
\hline 2007 & 0.84 & 0.66 & 13.0 & 4.10 & 30.04 & 14.80 & 22.16 & 23.21 & 91.75 & 75.26 & 87.13 & 91.54 & 86.38 & 70.48 & 16.16 & 15.74 & 1.06 & 1.06 & 16.50 & 11.09 & 1.83 & .94 \\
\hline $\begin{array}{l}2008 \\
2009\end{array}$ & $\begin{array}{l}1.27 \\
1.34\end{array}$ & $\begin{array}{l}0.78 \\
1.55\end{array}$ & $\begin{array}{l}19.02 \\
16.93\end{array}$ & $\begin{array}{l}8.11 \\
8.99\end{array}$ & $\begin{array}{l}43.30 \\
55.10\end{array}$ & $\begin{array}{l}21.07 \\
46.46\end{array}$ & $\begin{array}{c}20.98 \\
19.9\end{array}$ & $\begin{array}{l}18.48 \\
20.69\end{array}$ & $\begin{array}{l}86.51 \\
87.43\end{array}$ & $\begin{array}{l}78.20 \\
69.02\end{array}$ & $\begin{array}{l}89.08 \\
87.85\end{array}$ & $\begin{array}{l}84.35 \\
80.00\end{array}$ & $\begin{array}{l}81.24 \\
81.11\end{array}$ & & & & $\begin{array}{l}1.06 \\
1.07\end{array}$ & $\begin{array}{l}1.06 \\
1.07\end{array}$ & $\begin{array}{l}15.29 \\
14.09\end{array}$ & $\begin{array}{l}11.48 \\
9.19\end{array}$ & $\begin{array}{l}1.56 \\
1.27\end{array}$ & $\begin{array}{l}3.54 \\
2.49\end{array}$ \\
\hline Avg & 1.096 & 1.31 & 15.18 & 6.56 & 42.80 & 33.60 & 22.31 & 20.70 & 86.79 & 75.98 & 87.34 & 85.73 & 81.15 & 70.65 & 15.28 & 14.39 & 1.07 & 1.07 & 17.90 & 10.16 & 1.81 & 1.40 \\
\hline
\end{tabular}

Source: Author's calculation

Moreover, this shows that level of trust and confidence of the people is increasing in Islamic bank with the passage of time and also a manifestation of a positive attitude of the people for considering Islamic financial products as alternate and viable financing options.

5.3.2 LAR: Further analysis of LAR indicated that Bai'Murabaha has been the most famous and mostly used mode of financing followed by Ijarah, Export refinance under Islamic scheme, and Hire Purchase under Shirkatul Melk is standing second position. Records also shows that, the Islamic bank is potentially more profitable than conventional bank.

5.3.3 EM: Analysis of Equity Multiplier (EM) reveals that, the Islamic bank has used more debt to convert into assets with share capital. However the difference is little in comparison to conventional bank.

5.3.4 CR: Current Ratio for both type of bank almost same. That means, the both banks deserves good capability in case of paying obligations.

\subsection{Risk Analysis}

Analysis of the results of all the risk measures, Debt Equity Ratio (DER), Bad Debt Ratio(BDR), indicates conventional bank to be more risky and less solvent than Islamic bank. We observed in LDR that deposit base of Islamic bank is increasing rapidly over time and since deposits make the largest component of total liabilities of the bank. We also observed Bad Debt Ratio (BDR) of Islamic bank on the decreasing trend. The difference in these performance measures is suggests that these two types of bank do not fall in the same risk class. This confirms that product of Islamic banking is a viable investment class providing unique risk structure for interested investors.

\section{Conclusion}

Our findings on the investment performance measurement of Islamic banking in Bangladesh are different and at times mixed in comparison to the results drawn from the similar studies done in different parts of the world. For example, Kader and Asarpota (2007) found in their study that UAE Islamic banks are relatively more profitable, less liquid, less risky, and more efficient as compared to the UAE conventional banks. Samed \& Hassan (2000) revealed in their study that BIMB (Bank Islam Malaysia Berhad) is less profitable, relatively less risky and more solvent as compared to conventional banks of Malaysia. The difference in results is largely due to the fact that Islamic banking has longer history in these countries as compared to Bangladesh where Islamic banking system started merely few years back. Moreover, conventional banking has a longer history, deeper roots, vast experience of learning from the financial markets mechanisms, and larger share in the financial sector of Bangladesh. Considering these facts of the matter, we don't find the results of our study surprising. However, the way Islamic banking sector is improving and growing in Bangladesh, we expect Islamic banking of Bangladesh to be equally or even better in performance than conventional banking in the foreseeable future. Finally, for future studies, as the time passes, when there will be more Islamic banks to study and longer time period, a similar study would generate better insight on the issue of performance comparison and provide solid evidence one way or another. By then, we would gladly join the discussion again.

\section{REFERENCES}

Ahmed, Mareyah Mohammad \& Pandey, Dayanand, 2010. Are Islamic Banks Better Immunized than Conventional Banks in the Current Economic Crisis?. Paper presented at $10^{\text {th }}$ Global Conference on Business \& Economics held at Rome, Italy

Al Shammari, M., and Salimi, M. (1998). Modeling the operating efficiency of banks, A parametric methodology. Journal of Logistic Information Management, Vol. 11.

American Journal of lslamic Social Sciences (9) Summer: 219-232. and Suliman, M. O. (1993), "Equity Capital, Profit-Sharing Contracts and Investment: Theory and Evidence," Journal of Business Finance and Accounting

Ariff Mohamed, 'Research Report on Islamic Banking', Asian Pacific Economic Literature, Vol: 2, No:2, PP.46-62, University of Malaya.

Bashir, A. M., and Darrat, A. F. (1992), "Equity Participation Contracts and Investment,"

Cihak, M. and H. Hesse (2008), Islamic Banks and Financial Stability: An empirical analysis, IMF Working Paper No. 08.

Hassan, M., (2006), The X Efficiency of Islamic banks, Islamic Economic Studies, 13(2): 49-78.

Kader, Janbota M. \& Asarpota, Anju K., 2007. Comparative Financial Performance of Islamic vis-à-vis Conventional Banks in the UAE. Paper presented at 2006-2007 Annual Student Research Symposium \& First Chancellor's Undergraduate Research Award at UAE University

Samed Abdus \& Hassan, M. Kabir, 'The Performance of Malaysian Islamic Bank During 1984-1987: An Exploratory Study", International Journal of Islamic Financial Services Vol.1, No.3

Yudistira, Donsyah (2003), "Efficiency of Islamic Banks: an Empirical Analysis of 18 Banks, "Finance No. 0406007, EconWPA

Yudistira, Donsyah, 2004. Efficiency of Islamic Banks: an Empirical Analysis of 18 Banks. Islamic Economic Studies 12(1), 1-19

$--0--$ 
Appendix-A

Table 1: Balance Sheet of IBBL from 2005 to 2009 (Figure in Million tk)

\begin{tabular}{|l|l|l|l|l|l|}
\hline Particulars & $\mathbf{2 0 0 5}$ & $\mathbf{2 0 0 6}$ & $\mathbf{2 0 0 7}$ & $\mathbf{2 0 0 8}$ & $\mathbf{2 0 0 9}$ \\
\hline Cash in Hand & $1,285.56$ & $1,410.15$ & $2,907.14$ & $3,107.36$ & $2,480.77$ \\
\hline Cash with BB \& Other Banks/FIs & $17,135.82$ & $22,108.80$ & $14,169.31$ & $28,222.96$ & $35,004.90$ \\
\hline Cash with Other Banks/FIs & $1,775.32$ & $1,329.13$ & $4,012.33$ & $5,623.18$ & $7,678.38$ \\
\hline Investment in Shares \& Securities & $3,534.16$ & $3,557.76$ & $20,365.71$ & $7,532.61$ & $11,136.61$ \\
\hline Total Investment, Adv. \& Bills & $93,644.15$ & $113,575.07$ & $144,920.61$ & $180,053.94$ & $214,615.80$ \\
\hline Fixed Assets & $3,067.99$ & $3,724.69$ & $3,987.23$ & $4,407.22$ & $6,512.36$ \\
\hline Other Assets & $2,437.34$ & $4,547.22$ & $1,000.01$ & $1,931.87$ & 874.02 \\
\hline Total Assets & $\mathbf{1 2 2 , 8 8 0 . 3 5}$ & $\mathbf{1 5 0 , 2 5 2 . 8 2}$ & $\mathbf{1 9 1 , 3 6 2 . 3 5}$ & $\mathbf{2 3 0 , 8 7 9 . 1 4}$ & $\mathbf{2 7 8 , 3 0 2 . 8 4}$ \\
\hline Current A/Cs \& Others A/Cs & $12,411.23$ & $14,016.13$ & $19,165.15$ & $18,958.13$ & $23,794.37$ \\
\hline Bills Payable & 695.43 & 890.28 & $1,767.59$ & $2,308.04$ & $2,545.72$ \\
\hline Savings Bank Deposits & $43,386.77$ & $52,118.58$ & $62,403.50$ & $77,498.41$ & $95,081.55$ \\
\hline Term Deposits & $22,062.21$ & $25,872.28$ & $31,103.69$ & $36,706.85$ & $45,268.01$ \\
\hline Other Mudaraba Deposits & $29,223.78$ & $39,522.14$ & $51,885.35$ & $64,871.98$ & $77,602.50$ \\
\hline Deposits \& Other A/C & $107,779.42$ & $132,419.40$ & $166,325.29$ & $200,343.41$ & $244,292.15$ \\
\hline Other Liabilities & $6,885.19$ & $7,826.18$ & $13,195.73$ & $16,475.23$ & $13,905.15$ \\
\hline Total Outside Liabilities & $114,664.61$ & $140,245.59$ & $179,521.01$ & $216,818.64$ & $258,197.30$ \\
\hline Paid Up Capital & $2,764.80$ & $3,456.00$ & $3,801.60$ & $4,752.00$ & $6,177.60$ \\
\hline Reserves \& Others & $5,450.94$ & $6,551.23$ & $8,039.74$ & $9,308.49$ & $13,927.94$ \\
\hline Shareholders' Equity & $8,215.74$ & $10,007.23$ & $11,841.34$ & $14,060.49$ & $20,105.54$ \\
\hline Total Liab. \& Shareholders' Equity & $\mathbf{1 2 2 , 8 8 0 . 3 5}$ & $\mathbf{1 5 0 , 2 5 2 . 8 2}$ & $\mathbf{1 9 1 , 3 6 2 . 3 5}$ & $\mathbf{2 3 0 , 8 7 9 . 1 4}$ & $\mathbf{2 7 8 , 3 0 2 . 8 4}$ \\
\hline
\end{tabular}

Table 2: Income Statement of IBBL from 2005 to 2009 (Figure in Million tk)

\begin{tabular}{|l|l|l|l|l|l|}
\hline Particulars & 2005 & 2006 & 2007 & 2008 & 2009 \\
\hline Investment Income & $8,336.03$ & $11,158.06$ & $14,572.19$ & $19,543.84$ & $21,370.53$ \\
\hline Profit Paid on Deposit & $5,884.73$ & $8,019.34$ & $9,410.59$ & $12,162.10$ & $13,076.99$ \\
\hline Net Investment Income & $2,451.30$ & $3,138.72$ & $5,161.60$ & $7,381.74$ & $8,293.54$ \\
\hline Income from Investment in Share \& Securities & 90.50 & 137.38 & 284.00 & 408.76 & 115.16 \\
\hline Comm., Exchange \& Brokerage & $2,016.99$ & $2,456.73$ & $2,579.01$ & $3,337.52$ & $3,437.20$ \\
\hline Other Non Investment Income & 143.27 & 286.15 & 264.32 & 940.22 & 480.96 \\
\hline Total Operating Income & $\mathbf{4 , 7 0 2 . 0 6}$ & $\mathbf{6 , 0 1 8 . 9 7}$ & $\mathbf{8 , 2 8 8 . 9 4}$ & $\mathbf{1 2 , 0 6 8 . 2 3}$ & $\mathbf{1 2 , 3 2 6 . 8 6}$ \\
\hline Salary, Allowance \& PF & $1,170.99$ & $1,851.22$ & $2,037.23$ & $2,837.99$ & $3,153.35$ \\
\hline Other Operating Expenses & 662.21 & 852.45 & $1,089.35$ & $1,277.82$ & $1,392.62$ \\
\hline Total Operating Expenditure & $1,833.19$ & $2,703.67$ & $3,126.58$ & $4,115.81$ & $4,545.97$ \\
\hline Profit/Loss before Provisions & $2,868.86$ & $3,315.30$ & $3,162.36$ & $7,952.43$ & $7,780.89$ \\
\hline Prov. for Unclassified Investment & 286.20 & 508.79 & 436.76 & 310.02 & 384.26 \\
\hline Prov. for Classified Investment & 420.25 & $(107.26)$ & 653.62 & 528.51 & 939.60 \\
\hline Prov. For others Assets / Off Balance Sheet Items & - & 5.10 & 291.16 & 766.06 & -60.63 \\
\hline Net P/L before Taxes & $2,162.42$ & $2,908.67$ & $3,780.82$ & $6,347.83$ & $6,517.66$ \\
\hline Provisions for Tax & $1,036.60$ & $1,508.07$ & $1,731.77$ & $3,673.04$ & $3,114.11$ \\
\hline Net P/L after Tax & $\mathbf{1 , 1 2 5 . 8 2}$ & $\mathbf{1 , 4 0 0 . 5 9}$ & $\mathbf{2 , 0 4 9 . 0 5}$ & $\mathbf{2 , 6 7 4 . 8 0}$ & $\mathbf{3 , 4 0 3 . 5 5}$ \\
\hline
\end{tabular}

Appendix-B

Table 3 Financial Highlights of Mutual Trust Bank Ltd from 2005 to 2009 (figure in million tk)

\begin{tabular}{|l|l|l|l|l|l|}
\hline Particulars & $\mathbf{2 0 0 5}$ & $\mathbf{2 0 0 6}$ & $\mathbf{2 0 0 7}$ & $\mathbf{2 0 0 8}$ & $\mathbf{2 0 0 9}$ \\
\hline Paid up Capital & 864.00 & 950.40 & 997.92 & $1,496.88$ & $1,766.32$ \\
\hline Total Capital & 1692.52 & 311.53 & $2,370.95$ & $2,888.33$ & $3,969.33$ \\
\hline Surplus in Capital Fund & 478.57 & 506.00 & 43.12 & 107.24 & 952.56 \\
\hline Total Assets & $\mathbf{1 9 , 3 0 6 . 9 9}$ & $\mathbf{2 6 , 2 1 7 . 9 9}$ & $\mathbf{3 2 , 1 8 1 . 9 0}$ & $\mathbf{3 8 , 9 6 4 . 9 7}$ & $\mathbf{5 2 , 7 7 4 . 7 7}$ \\
\hline Total Deposits & $16,098.54$ & $22,264.05$ & $24,776.92$ & $33,820.41$ & $42,354.07$ \\
\hline Total Loans and Advances & $14,373.26$ & $18,591.52$ & $22,683.23$ & $28,529.35$ & $33,883.92$ \\
\hline Total Contingent Liabilities & 7498.27 & $9,671.39$ & $10,916.14$ & $11,467.71$ & $10,061.04$ \\
\hline Classified Loans as \% of Total loans and advances & Nil & $1.03 \%$ & $2.39 \%$ & $4.92 \%$ & $2.81 \%$ \\
\hline Profit after provision and tax & 336.17 & 478.28 & 210.8 & 305.03 & 820.61 \\
\hline Total Classified loans during the year & Nil & 191.63 & 541.64 & $1,402.85$ & 952.76 \\
\hline Total provision maintained against classified loans & Nil & 30.30 & 217.43 & 829.33 & 663.09 \\
\hline Surplus in provision against classified loans & Nil & 0.03 & 0.30 & 0.09 & 2.26 \\
\hline Cost of Fund & $8.96 \%$ & $10.33 \%$ & $9.15 \%$ & $10.18 \%$ & $10.21 \%$ \\
\hline Earning assets & $17,419.05$ & $23,575.83$ & $28,470.97$ & $33,944.60$ & $46,075.04$ \\
\hline Non-interest earning assets & 1887.94 & $2,642.16$ & $3,710.93$ & $5,020.37$ & 6699.72 \\
\hline Income from Investments & 139.97 & 184.40 & 162.41 & 454.84 & 857.47 \\
\hline Profit per Share (Figure in Taka) & 35.37 & 50.32 & 21.12 & 17.27 & 46.46 \\
\hline Price-Earning ratio (Times) & 11.35 & 6.80 & 28.24 & 18.52 & 8.86 \\
\hline
\end{tabular}

